\title{
ARNTL2 wt Allele
}

National Cancer Institute

\section{Source}

National Cancer Institute. ARNTL2 wt Allele. NCI Thesaurus. Code C119696.

Human ARNTL2 wild-type allele is located within 12p12.2-p11.2 and is approximately 90 $\mathrm{kb}$ in length. This allele, which encodes aryl hydrocarbon receptor nuclear translocatorlike protein 2, is involved in both transcriptional activation and circadian rhythms. 